\title{
ASSESSMENT AND EVALUATION OF TENDERS IN PUBLIC PROCUREMENT IN THE CZECH REPUBLIC
}

\author{
[Posouzení a hodnocení nabídek při zadávání veřejných zakázek \\ v České republice] \\ Danuta Duda ${ }^{1}$ \\ ${ }^{1}$ Slezská univerzita, Obchodně podnikatelská fakulta, Univerzitní nám. 1934/3,73340 Karviná \\ Email:duda@opf.slu.cz.
}

\begin{abstract}
The article deals with the assessment and evaluation of tenders in public procurement in the Czech Republic. Evaluation and assessment of tenders is one of the most important stages of public procurement and has an influence on selection of the best tender. Therefore, it is necessary to set up the criteria rightly in order to choose the most advantageous tender. Evaluation of tenders is realized by the evaluation committee, it must proceed exactly according to the established evaluation criteria. Evaluation and assessment must be carried out in accordance with the principles of transparency and non-discrimination of tenderers. The article also includes evaluating and assessing specific public contracts with the help of a multi-criteria decision analysis, namely the methods: the Weighted Sum Approach (WSA) and the Technique for Order Preference by Similarity to an Ideal Solution (TOPSIS), which can be used in practice. The aim of this article is to describe and evaluate the issue of assessment and evaluation of tenders in public procurement in the Czech Republic and also includes evaluating and assessing specific public contracts with the help of a multi-criteria decision analysis, WSA and TOPSIS.
\end{abstract}

Keywords: assessment tenders, evaluation tenders, multi-criteria decision analysis, public contracts.

JEL classification: K39, C39

Doručeno redakci: 22.6.2016; Recenzováno: 5.7.2016; 25.8.2016; Schváleno k publikování: 30.11.2016

\section{Introduction}

Public sector procurement is a hugely important part of a government's influence on the economy, both in terms of its size and the way in which it is conducted (Europe Economics 2015). Public Procurement is an indispensable economic activity for good governance (Kashap 2004), it is a key economic activity of governments that represents a significant percentage of the Gross Domestic Product. An effective procurement system plays a strategic role in governments for avoiding mismanagement and waste of public funds. Of all government activities, public procurement is also one of the most vulnerable to fraud and corruption (OECD Principles for Integrity in Public Procurement 2009).

The aim of this article is to describe and evaluate the issue of assessment and evaluation of tenders in public procurement in the Czech Republic and also includes evaluating and assessing specific public contracts with the help of a multi-criteria decision analysis, WSA and TOPSIS.

\section{Assessment and Evaluation of Tenders in Public Procurement}

Evaluation of tenders is one of the most important stages of public procurement and has an influence on selection of the best tenders. When determining the evaluation criteria many factors need to be taken into account, it is important to realize that every public contract is different. Public procurement rules in the European Union require that public contracting authorities must publish all tender evaluation criteria and its weights in advance. In order to define sound weights, the authors argue that the scoring rules for all evaluation criteria must 
be defined beforehand (Mateus et al. 2010). The contracting authority shall accord relative weightings expressed in percentages to the individual partial evaluation criteria or establish another mathematical interrelationship between partial criteria (Krč 2013). The evaluation process must lead to selection of the economic operator.

According to Thaie (2009) scoring should be published in such a way that tenderers, when preparing their tenders, had accurate and meaningful information on evaluation criteria of a relevant public contract. According to Jurčík (2014) the contracting authority shall state the relative scale which is given to each of the criteria chosen to determine the most advantageous tender in the tender documentation, with the exception of cases where the only criterion is the price. The law does not specify what percentage should be determined by the price and what percentage should be determined by other evaluation criteria. The decision is up to the contracting authority that is governed by a subject of a public contract and also by his own needs (Śmigulska-Wojciechowska 2014). The contracting authority shall indicate the criteria in descending order according to the importance. The evaluation of public contracts is a key stage of the procedure for public procurement. The evaluation of public procurement is a phase of the award procedure, which based on the complete and appropriate tenders of tenderers, leads to the selection of the economic operator. Each tender must be evaluated by the evaluation committee. The main task of the evaluation committee is the evaluation of tenders and evaluation of tenderers' fulfilment of requirements of the award procedure. Members of the evaluation committee may exclude the tenderer or the tender from the award procedure (Granecki 2014). Evaluation and assessment must be carried out in accordance with the principles of transparency and non-discrimination of tenderers. According to Jurčík (2014) the evaluation committee, by the time of the evaluation of tenders at the latest, may consider that the tender of one of the tenderers is abnormally low and may exclude the tenderer. A higher number of tenders is for the contracting entity desirable, because it reduces likelihood the unfair acts on the part of tenderers. The more tenders contracting authority receives, the lower is the resulting tendered price. These allegations are proven a lot of research, for example (Pavel 2010), (Onur et al. 2012), (Brannman et al. 1987), (Gineitiené et al. 2011) and (Carr 2005).

\section{Assessment and Evaluation of Tenders in Public Procurement in the Czech Republic} According to $\S 78$ of the Act No. 137/2006 Coll. on Public Contracts, as amended basic evaluation criterion for the award of a public contract shall be (a) economic advantageousness of the tender, or (b) the lowest tender price. The contracting entity shall select the basic evaluation criterion according to the type and complexity of the public contract and indicate it in the contract notice or in the call for competition. If the contracting authority decides to award a public contract according to the basic evaluation criterion of the most economically advantageous tender, it shall always establish partial evaluation criteria, so as to express the relationship between the use value and the price. Such partial evaluation criteria shall be linked to the performance of the public contract offered. They may, in particular, involve a tender price, quality, technical merit of the performance offered, aesthetical and functional characteristics, environmental characteristics, impact on the employment of people with disabilities, operational costs, cost-effectiveness, sales and after-sales service, technical assistance, delivery period or period of completion. Contractual terms and conditions, the purpose of which is to secure the obligations of the economic operator, or terms of payment cannot be partial evaluation criteria. If the basic evaluation criterion of the lowest tender price is applied, the evaluation committee shall establish the ranking of tenders in accordance with the tender price. In the Czech Republic, majority of award procedures sets out only the criterion of the lowest tender price (Jurčík 2015). According to Pavel and Ochrana (2013) in 
the case study on the local level of government, contracting entities in the Czech Republic typically prefer a single evaluation criterion. Such a procedure is, of course, legal. Provided the contracting entity chooses to select the tender price as the only criterion, it is then, however, desirable that this criterion is in substance consistent with the principle of efficient use of resources. In other words, the purpose (goal) of the tender should be fulfilled in return for the expended cost. This could be achieved by defining specific requirements in tender documents and including them in the contract between the contracting entity and the supplier. Qualifications may not be the subject of evaluation criteria.

According to Radziszewska - Zielina (2011) the most advantageous offer is either the one which has the most advantageous balance of the price and other criteria related to the object of the tender or the one which offers the lowest price (if the price was the only criterion). Sample tender assessment criteria: price, deadline, guarantee of quality (years), payment conditions (e.g. invoice payment postponement date), functionality (parameters), ecology (parameters).

Table 1 shows that in 2015 the proportion of award procedures using the lowest tender price as the basic evaluation criterion was $82.4 \%$ of all award procedures which were published in the Bulletin of public contracts in the Czech Republic, in 2014 it was $81.8 \%$ of award procedures, in 2013 it was $78.6 \%$, in 2012 it was $69.2 \%$, in $201160.9 \%$, in $201055 \%$ and in $200954.6 \%$.

Table 1: Analysis of trends of evaluation criteria used in 2009-2015

\begin{tabular}{|c|c|c|c|}
\hline Year & $\begin{array}{c}\text { The share of award procedures, in which } \\
\text { "the lowest tender price" was used as the } \\
\text { basic evaluation criterion }\end{array}$ & $\begin{array}{c}\text { The share of award procedures, in which } \\
\text { "economic advantageousness of the tender" } \\
\text { was used as the basic evaluation criterion }\end{array}$ & Unknown \\
\hline 2015 & $82,4 \%$ & $11,3 \%$ & $6,3 \%$ \\
\hline 2014 & $81,8 \%$ & $14,0 \%$ & $4,3 \%$ \\
\hline 2013 & $78,6 \%$ & $16,9 \%$ & $4,5 \%$ \\
\hline 2012 & $69,2 \%$ & $26,0 \%$ & $4,9 \%$ \\
\hline 2011 & $60,9 \%$ & $33,5 \%$ & $5,6 \%$ \\
\hline 2010 & $55,0 \%$ & $39,8 \%$ & $5,2 \%$ \\
\hline 2009 & $54,6 \%$ & $40,8 \%$ & $4,7 \%$ \\
\hline
\end{tabular}

Source: Author's own processing based on the data from Hospodářská komora České republiky: Výroční zpráva o stavu veřejných zakázek v České republice za rok 2015 [online] [cit. 2016-06-04].

Available from <http://www.komora.cz/pro-podnikani/legislativa-a-normy/pripominkovani-legislativy/novematerialy-k-pripominkam/107-16-vyrocni-zprava-o-stavu-verejnych-zakazek-v-ceske-republice-za-rok-2015-t16-5-2016.aspx>.

From Figure 1 it is obvious that the proportion of award procedures increased in 2009-2015 in which the lowest tender price was used as the basic evaluation criterion (and this obviously reduces the proportion of award procedures for which economic advantageousness of the tender was used as the basic evaluation criterion). Contracting authorities are afraid they will not be able to set the parameters of the evaluation criteria of "economic advantageousness of the tender" (especially partial evaluation criteria which cannot be expressed numerically) objectively and transparently in order to demonstrate full evaluation procedure to the Office for the Protection of Competition, or in case of a control and an audit, and therefore it leads to an excessive evaluation according to the basic evaluation criterion which is "the lowest tender price" (Ministry of Regional Development 2014). 
Figure 1: The share of award procedures in which "the lowest tender price" was used as the basic evaluation criterion in 2009-2015

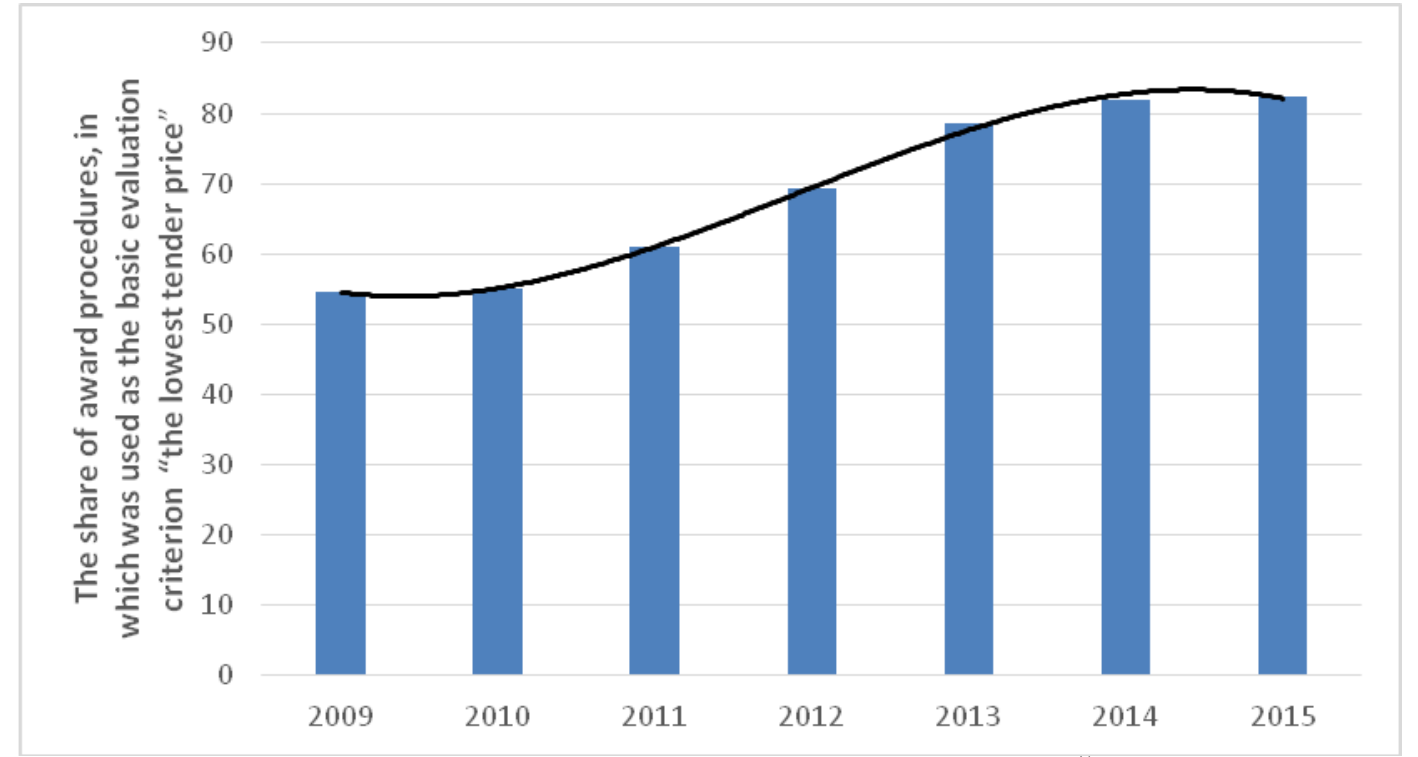

Source: Author's own processing based on data from Hospodářská komora České republiky: Výroční zpráva o stavu veřejných zakázek v České republice za rok 2015 [online] [cit. 2016-06-04].

Available from <http://www.komora.cz/pro-podnikani/legislativa-a-normy/pripominkovani-legislativy/novematerialy-k-pripominkam/107-16-vyrocni-zprava-o-stavu-verejnych-zakazek-v-ceske-republice-za-rok-2015-t16-5-2016.aspx>.

On $28^{\text {th }}$ March 2014 new procurement directives on public procurement were published. Specifically, the Directive 2014/23/EU of the European Parliament and of the Council of 26th February 2014 on the award of concession contracts, Directive 2014/24/EU of the European Parliament and of the Council of 26th February 2014 on public procurement and repealing Directive 2004/18/EC, Directive 2014/25/EU of the European Parliament and of the Council of 26th February 2014 on procurement by entities operating in the water, energy, transport and postal services sectors and repealing of the Directive 2004/17/EC. The deadline for their implementations into national legislations of Member States was 18th April 2016.

New Act No. 134/2016 on Public Procurement shall come into force on 1st October 2016, this Act was adopted on 19th April 2016.

Regarding the issue of assessment and evaluation of tenders, Article 67 of the Directive 2014/24/EU determines economic advantageousness of the tender as the sole criterion for awarding public contracts. The award of public contracts according to the lowest tender price is not stated in this Directive. Although it seems that the use of the lowest tender price as the sole criterion has been banned, it is not so. In Article 67 paragraph 2 of the Directive 2014/24 the most economically advantageous tender from the point of view of the contracting authority shall be identified on the basis of the price or cost, using a cost-effectiveness approach, such as life-cycle costing and may include the best price-quality ratio, which shall be assessed on the basis of criteria, including qualitative, environmental and/or social aspects, linked to the subject-matter of the public contract in question. According to Skálová (2015) it seems that new procurement directive does not bring any revolutionary change from the status quo. Moreover, according to Act No. 137/2006 Coll., on Public Contracts contracting authority may and must consider and decide whether the specific subject of the tender is preferable to use one evaluation criterion (ie. price) or whether to choose partial evaluation criteria. 
In $\S 114$ Act No. 134/2016 on Public Procurement it is stated that the economic advantage of offers shall be evaluated on the basis of the most favourable ratio between the tender price and quality ratio, including life-cycle cost and quality. The contracting authority may evaluate the economic advantageousness of the tender also according to the lowest tender price and the lowest life cycle cost.

The problem that the contracting authorities will use the lowest tender price as the only evaluation criterion in most cases will persist and thus the substandard economic operators will be chosen. Therefore, in my opinion, the tender price as the only evaluation criterion should be permissible only in exceptional cases.

\section{Multi-criteria decision analysis}

For the selection of the best tenders the following methods have been used by the author: the Weighted Sum Approach (WSA) and the Technique for Order Preference by Similarity to an Ideal Solution (TOPSIS). They were only used these two methods due to the limited extent of the number of pages in this article.

The Weighted Sum Approach (WSA) method is based on linear utility function. This method computes the global utility of the alternatives as the weighted sum of normalized criterion values. The method provides complete ranking of alternatives according to their global utilities. The WSA procedure consists of the following three steps (Jablonsky and Fiala 2003; Dvorský et al. 2006); Data Normalization; the original data are usually in different units of measure, so it is necessary to unify these units or to get rid of them. The WSA method uses the equation:

$$
\mathrm{r}_{i j}=\frac{\mathrm{y}_{i j}-\mathrm{D}_{j}}{\mathrm{H}_{j}-\mathrm{D}_{j}}
$$

Where $r_{i j}$ are the normalized values for $i$ alternative and $j$ criterion, $D_{j}$ are the values of the basal alternative and $H_{j}$ are the values of the ideal alternative. The basal alternative is theoretically the worse alternative (artificially created) that could exist, it has the worse values selected from each criterion. The ideal alternative is the opposite, so it has the best values in each criterion. If the ideal alternative really exists, then it would be the top alternative in the order. Via this recalculation, the comparability of the values is assured. Values $r_{i j}$ are from the interval $(0,1)$. The way of the normalization has one disadvantage $-\mathrm{a}$ big difference between the maximum and the minimum value of one criterion can influence the results.

Evaluation of the Utility of Each Alternative; the "utility" means total evaluation of the given alternative $(u(a i))$ according to all the criteria mentioned above. We obtain the utility if we sum up normalized values $r_{i j}$ multiplied by weights of the criteria $v_{j}$, so the equation is:

$$
u\left(a_{i}\right)=\sum_{j=1}^{k} v_{j} r_{i j}
$$

Order of Alternatives; according to the utilities we can order all the alternatives; the first one has the highest utility (Dinçer 2011).

The Technique for Order Preference by Similarity to an Ideal Solution (TOPSIS). Regarding the TOPSIS method this is again the question of the principle of maximization of distance from an ideal variant. The ideal variant means that all criteria have the best assessments. The ideal variant is mostly suppositional; the best of variants is the one which is 
the nearest to the ideal variant. Vector $\left(\mathrm{H}_{1}, \mathrm{H}_{2}, \ldots, \mathrm{H}_{\mathrm{J}}\right)$ represents ideal variant, vector $\left(\mathrm{D}_{1}\right.$, $\left.\mathrm{D}_{2}, \ldots, \mathrm{D}_{\mathrm{J}}\right)$ represents the basal variant.

The initial step is a construction of criteria-normalised matrix $R=\left(r_{i j}\right)$, for calculation of normalised values the following formula is proposed:

$$
r_{i \mathrm{j}}=\frac{\mathrm{y}_{\mathrm{ij}}}{\sqrt{\sum_{\mathrm{i}=1}^{\mathrm{I}}\left(\mathrm{y}_{\mathrm{ij}}\right)^{2}}}
$$

After this transformation vectors with unit size are in columns of matrix $\mathrm{R}$. The next step is calculation of the criteria-weighted matrix $W$ so that each $j$-th column of the criterianormalised matrix $R$ multiplies by appropriate the weight $v_{j}$.

$$
\mathrm{W}=\left[\begin{array}{cccc}
\mathrm{w}_{11} & \mathrm{w}_{12} & \ldots & \mathrm{w}_{1 \mathrm{~J}} \\
\vdots & \vdots & & \vdots \\
\vdots & \vdots & & \vdots \\
\mathrm{w}_{\mathrm{I} 1} & \mathrm{w}_{\mathrm{I} 2} & \ldots & \mathrm{w}_{\mathrm{IJ}}
\end{array}\right]=\left[\begin{array}{cccc}
\mathrm{v}_{1} \mathrm{r}_{11} & \mathrm{v}_{2} \mathrm{r}_{12} & \ldots & \mathrm{v}_{\mathrm{J}} \mathrm{r}_{1 \mathrm{I}} \\
\vdots & \vdots & & \vdots \\
\vdots & \vdots & & \vdots \\
\mathrm{v}_{1} \mathrm{r}_{\mathrm{I} 1} & \mathrm{v}_{2} \mathrm{r}_{\mathrm{I} 2} & \ldots & \mathrm{v}_{\mathrm{J}} \mathrm{r}_{\mathrm{IJ}}
\end{array}\right]
$$

Now we define the ideal variant $\left(\mathrm{H}_{1}, \mathrm{H}_{2}, \ldots, \mathrm{H}_{\mathrm{J}}\right)$ and the basal variant $\left(\mathrm{D}_{1}, \mathrm{D}_{2}, \ldots, \mathrm{D}_{\mathrm{J}}\right)$ respecting values of criteria-weighted matrix:

$$
\begin{aligned}
& \mathrm{H}_{\mathrm{j}}=\max _{\mathrm{i}}\left(\mathrm{W}_{\mathrm{ij}}\right) \\
& \mathrm{D}_{\mathrm{j}}=\min _{\mathrm{i}}\left(\mathrm{W}_{\mathrm{ij}}\right)
\end{aligned}
$$

The next step is calculation of the distance of variants from the ideal variant:

$$
\mathrm{d}_{\mathrm{i}}^{+}=\sqrt{\sum_{\mathrm{j}=1}^{\mathrm{J}}\left(\mathrm{w}_{\mathrm{ij}}-\mathrm{H}_{\mathrm{j}}\right)^{2}}
$$

and the distance of variants from the basal variant:

$$
d_{i}^{-}=\sqrt{\sum_{j=1}^{I}\left(w_{i j}-D_{j}\right)^{2}}
$$

The calculation of the relative index of the distance of variants from the basal variant is following:

$$
\mathrm{c}_{\mathrm{i}}=\frac{\mathrm{d}_{\mathrm{i}}^{-}}{\mathrm{d}_{\mathrm{i}}^{+}+\mathrm{d}_{\mathrm{i}}^{-}}
$$

The alternatives are ranked according to the declining indicator $\mathrm{c}_{\mathrm{i}}$ (Dvorský et al. 2006).

\section{The assessment and evaluation tenders in practice using multi-criteria decision analysis}

In the case where economic advantageousness of the tender is the basic evaluation criterion, the evaluation committee must evaluate tenders and prioritize their individual partial 
evaluation criteria. The evaluation committee most often uses the scoring method. On the selection of a specific public contracts, where the basic criterion for awarding the contract is the economic advantageousness of the tender, the methods of multi-criteria decision analysis will be applied, namely the methods WSA and TOPSIS and in order to ascertain whether the winner of the public tender on the basis of these two criteria is always the same tenderer. Obviously, a public contract that involves at least two evaluation criteria has been chosen. Due to the limited extent of the number of pages in this article are only two practical examples.

Contracting Body: Královéhradecký region, Pivovarské náměstí 1245, 50003 Hradec Králové

The subject-matter of a public contract: Complete reconstruction of the bridge, registration number 327-026 and adjustment of the road II/327 on both forelands of the bridge to the necessary extent.

Criteria for evaluation of tenders: The evaluation criteria in the public procurement and scales that are assigned to individual criteria are mentioned in Table 2.

Table 2: Criteria for evaluation of tenders

\begin{tabular}{|c|l|c|}
\hline Order & \multicolumn{1}{|c|}{ Criterion } & Scales \\
\hline 1. & The Offer Price without VAT & $85 \%$ \\
\hline 2. & The period of implementation of the construction & $15 \%$ \\
\hline
\end{tabular}

Source: Zpráva o posouzení a hodnocení nabídek [online] [cit. 2016-02-07]. Available from <file:///C:/Users/uzivatel/Downloads/zpr\%C3\%A1va\%20o\%20posouzen\%C3\%AD\%20a\%20hodnocen\%C3\%A $\mathrm{D} \% 20$ nab\%C3\%ADdek\%20(2).pdf>.

\section{Tenderers:}

1. MPS Mostní a pozemní stavby engineering, s.r.o., Čepí 104, 53332 Čepí

2. MATEX HK s.r.o., Kladská 181/55, 50003 Hradec Králové

3. M-Silnice a.s., Husova 1697, 53003 Pardubice

4. M-STAV CZ s.r.o., Husova 1805, 53003 Pardubice

5. MADOS MT s.r.o., Lupenice 51, 517 41, Kostelec nad Orlicí

The tenderers (order above) along with the price offered in Czech crowns and the period of implementation of the construction (ie. two criteria, which the contracting authority for the public contract evaluates) are mentioned in Table 3.

Table 3: A list of tenderers of the public contract „Complete reconstruction of the bridge, registration number 327-026 and adjustment of the road II/327“" with criteria

\begin{tabular}{|c|c|c|}
\hline Tenderer & The Offer Price without VAT (CZK) & $\begin{array}{c}\text { The period of implementation of the } \\
\text { construction (in weeks) }\end{array}$ \\
\hline 1. & 2560988,22 & 16 \\
\hline 2. & 2745964 & 18 \\
\hline 3. & 2802815,9 & 17 \\
\hline 4. & 2782050,35 & 18 \\
\hline 5. & 2811448,97 & 18 \\
\hline
\end{tabular}

Source: Zpráva o posouzení a hodnocení nabídek [online] [cit. 2016-02-07]. Available from <file:///C:/Users/uzivatel/Downloads/zpr\%C3\%A1va\%20o\%20posouzen\%C3\%AD\%20a\%20hodnocen\%C3\%A D\%20nab\%C3\%ADdek\%20(2).pdf>.

\section{a) The Weighted Sum Approach (WSA)}

$\begin{array}{lll}\text { Criteria } & \text { Price (PLN) } & \text { Additional guarantee (months) } \\ \text { Type criteria } & \text { Min } & \text { Max }\end{array}$

In Table 4 the criterion matrix to maximization criteria is modified. 
Table 4: Modification of a criterion matrix to maximization criteria

\begin{tabular}{|c|c|c|}
\hline Tenderer 1 & 250460,75 & 2 \\
\hline Tenderer 2 & 65484,97 & 0 \\
\hline Tenderer 3 & 8633,07 & 1 \\
\hline Tenderer 4 & 29398,62 & 0 \\
\hline Tenderer 5 & 0 & 0 \\
\hline
\end{tabular}

Source: drawn from MCA7 program

In Table 5 max $\mathrm{H}$ and min $\mathrm{D}$ of the value of each column are determined.

Table 5: Determination of max $\mathrm{H}$ and min $\mathrm{D}$ of the value of each column

\begin{tabular}{|c|c|c|}
\hline $\mathrm{H}$ & 250460,75 & 2 \\
\hline $\mathrm{D}$ & 0 & 0 \\
\hline
\end{tabular}

Source: drawn from MCA7 program

The vector weights of criteria is normalized vector weights

$0,85 \quad 0,15 \quad 1$

In Table 6 the criterion matrix is normalized.

Table 6: Normalized criterion matrix

\begin{tabular}{|c|c|}
\hline 1,000 & 1,000 \\
\hline 0,261 & 0,000 \\
\hline 0,034 & 0,500 \\
\hline 0,117 & 0,000 \\
\hline 0,000 & 0,000 \\
\hline
\end{tabular}

Source: drawn from MCA7 program

In Table 7 the utility function is calculated.

Table 7: Calculation of the utility function

\begin{tabular}{|c|c|}
\hline Tenderer 1 & 1,000 \\
\hline Tenderer 2 & 0,222 \\
\hline Tenderer 3 & 0,104 \\
\hline Tenderer 4 & 0,100 \\
\hline Tenderer 5 & 0,000 \\
\hline
\end{tabular}

Source: drawn from MCA7 program

In Table 8 the tenders of tenderers are sorted from the best one to the worst.

Table 8: Tenders of tenderers sorted from the best to the worst

\begin{tabular}{|c|c|}
\hline Tenderer 1 & 1,000 \\
\hline Tenderer 2 & 0,222 \\
\hline Tenderer 3 & 0,104 \\
\hline Tenderer 4 & 0,100 \\
\hline Tenderer 5 & 0,000 \\
\hline
\end{tabular}

Source: drawn from MCA7 program

\section{b) The TOPSIS method}

In Table 9 the criterion matrix to maximization criteria is modified.

Table 9: Modification of the criterion matrix to maximization criteria

\begin{tabular}{|c|c|c|}
\hline Tenderer 1 & 250460,75 & 2 \\
\hline Tenderer 2 & 65484,97 & 0 \\
\hline Tenderer 3 & 8633,07 & 1 \\
\hline Tenderer 4 & 29398,62 & 0 \\
\hline Tenderer 5 & 0 & 0 \\
\hline
\end{tabular}

Source: drawn from MCA7 program 
In Table 10 the matrix is normalized for comparability of the data.

Table 10: The normalized matrix for comparability of the data

\begin{tabular}{|c|c|}
\hline 0,961 & 0,894 \\
\hline 0,251 & 0,000 \\
\hline 0,033 & 0,447 \\
\hline 0,113 & 0,000 \\
\hline 0,000 & 0,000 \\
\hline
\end{tabular}

Source: drawn from MCA7 program

The vector weights of criteria is normalized vector weights
0,85
0,15

In Table 11 the weighted criterion matrix is calculated.

Table 11: The calculated weighted criterion matrix

\begin{tabular}{|c|c|}
\hline 0,817 & 0,134 \\
\hline 0,214 & 0,000 \\
\hline 0,028 & 0,067 \\
\hline 0,096 & 0,000 \\
\hline 0,000 & 0,000 \\
\hline
\end{tabular}

Source: drawn from MCA7 program

In Table 12 an ideal and a basal variants are determined.

Table 12: Determination of an ideal and a basal variant

\begin{tabular}{|c|c|c|}
\hline H & 0,817 & 0,134 \\
\hline D & 0,000 & 0,000 \\
\hline
\end{tabular}

Source: drawn from MCA7 program

In Table 13 the distance from an ideal and a basal variants are calculated.

Table 13: Calculation of the distance from an ideal and a basal variant

\begin{tabular}{|c|c|c|c|}
\hline & di+ & di- & $\mathrm{Ci}$ \\
\hline Tenderer 1 & 0,000 & 0,828 & 1,000 \\
\hline Tenderer 2 & 0,618 & 0,214 & 0,257 \\
\hline Tenderer 3 & 0,791 & 0,073 & 0,084 \\
\hline Tenderer 4 & 0,733 & 0,096 & 0,116 \\
\hline Tenderer 5 & 0,828 & 0,000 & 0,000 \\
\hline
\end{tabular}

Source: drawn from MCA7 program

In Table 14 the tenders of tenderers are sorted from the best one to the worst.

Table 14: Tenders of tenderers sorted from the best to the worst

\begin{tabular}{|c|c|}
\hline Tenderer 1 & 1,000 \\
\hline Tenderer 2 & 0,257 \\
\hline Tenderer 4 & 0,116 \\
\hline Tenderer 3 & 0,084 \\
\hline Tenderer 5 & 0,000 \\
\hline
\end{tabular}

Source: drawn from MCA7 program

Based on the above methods of the multi-criteria decision analysis (ie. methods WSA and TOPSIS) it may be concluded that the winner of the public contract (based on both methods) will be the real winner of this public contract, ie. MPS Mostní a pozemní stavby engineering, s.r.o., Čepí 104, 53332 Čepí. Regarding the sequence of other tenderers in the award procedure, it is not quite the same (see Table 8 and Table 14). Certainly, these methods of the 
multi-criteria decision analysis could be applied by contracting authorities in assessing their public procurements.

The multi-criteria decision analysis can be used even if several evaluation criteria exist, for example four.

Contracting Body: Health center Prosek a.s.

The subject-matter of a public contract: „Photovoltaic power plant FVE Health centre Prosek" supply and installation of solar power plants in the contracting body's seat

Criteria for evaluation of tenders: The evaluation criteria in the public procurement and scales that are assigned to individual criteria are mentioned in Table 15. This public contract has more than two evaluation criteria.

Table 15: Criteria for evaluation of tenders

\begin{tabular}{|c|c|c|}
\hline Order & Criterion & Scales \\
\hline 1. & The Offer Price without VAT & $80 \%$ \\
\hline 2. & The length of the warranty for quality work & $10 \%$ \\
\hline 3. & The amount of the contractual penalties for failure to meet the deadline for completing the work & $5 \%$ \\
\hline 4. & The period of implementation of the work & $5 \%$ \\
\hline
\end{tabular}

Source: Zpráva o posouzení a hodnocení nabídek [online] [cit. 2016-02-07]. Available from <http://www.poliklinikaprosek.cz/soubor-zprava-o-posouzeni-a-hodnoceni-nabidek-39-.pdf> .

\section{Tenderers:}

1. ETL-Ekotherm a.s., Praha 2, Sekaninova 192/48, PSČ 12800

2. JEKU, s.r.o., Libochovice, Vrchlického 380, PSČ 41117

The tenderers (order above) along with the price offered in Czech crowns, the length of the warranty for quality work, the amount of the contractual penalties for failure to meet the deadline for completing the work and period of implementation of the work (ie. four criteria, which the contracting authority for the public contract evaluates) are mentioned in Table 16.

Table 16: A list of tenderers of the public contract „Photovoltaic power plant FVE Health centre Prosek" supply and installation of solar power plants in the contracting body's seat with criteria

\begin{tabular}{|c|c|c|c|c|}
\hline Tenderer & $\begin{array}{c}\text { The Offer Price } \\
\text { without VAT } \\
\text { (in CZK) }\end{array}$ & $\begin{array}{c}\text { The length of the } \\
\text { warranty for quality work } \\
\text { (in months) }\end{array}$ & $\begin{array}{c}\text { The amount of the contractual penalties } \\
\text { for failure to meet the deadline for } \\
\text { completing the work (in CZK) }\end{array}$ & $\begin{array}{c}\text { The period of } \\
\text { implementation of } \\
\text { the work (in days) }\end{array}$ \\
\hline 1. & 4327845,50 & 72 & 12983 & 61 \\
\hline 2 & 4778706,10 & 36 & 2867 & 76 \\
\hline
\end{tabular}

Source: Zpráva o posouzení a hodnocení nabídek [online] [cit. 2016-02-07]. Available from 〈http://www.poliklinikaprosek.cz/soubor-zprava-o-posouzeni-a-hodnoceni-nabidek-39-.pdf〉.

\section{a) The Weighted Sum Approach (WSA)}

$\begin{array}{lccc}\text { Criteria } & \begin{array}{c}\text { The Offer Price } \\ \text { without VAT } \\ \text { (in CZK) }\end{array} & \begin{array}{c}\text { The length of the } \\ \text { warranty for quality work } \\ \text { (in months) }\end{array} & \begin{array}{c}\text { The amount of the contractual penalties } \\ \text { for failure to meet the deadline for } \\ \text { completing the work (in CZK) }\end{array} \\ \begin{array}{l}\text { Type } \\ \text { criteria }\end{array} & \text { Min } & \text { Max } & \text { Max }\end{array}$

The period of implementation of the work (in days) Min

In Table 17 a criterion matrix to maximization criteria is modified.

Table 17: Modification of a criterion matrix to maximization criteria

\begin{tabular}{|c|c|c|c|c|}
\hline Tenderer 1 & 450860,6 & 72 & 12983 & 15 \\
\hline Tenderer 2 & 0 & 36 & 2867 & 0 \\
\hline
\end{tabular}

Source: drawn from MCA7 program 
In Table 18 max $\mathrm{H}$ and min $\mathrm{D}$ of the value of each column are determined.

Table 18: Determination of max $\mathrm{H}$ and min $\mathrm{D}$ of the value of each column

\begin{tabular}{|c|c|c|c|c|}
\hline $\mathrm{H}$ & 450860,6 & 72 & 12983 & 15 \\
\hline $\mathrm{D}$ & 0 & 36 & 2867 & 0 \\
\hline
\end{tabular}

Source: drawn from MCA7 program

The vector weights of criteria is normalized vector weights

$\begin{array}{lllll}0,8 & 0,1 & 0,05 & 0,05 & 1\end{array}$

the sum of the weights

In Table 19 the criterion matrix is normalized.

Table 19: Normalized criterion matrix

\begin{tabular}{|c|c|c|c|}
\hline 1,000 & 1,000 & 1,000 & 1,000 \\
\hline 0,000 & 0,000 & 0,000 & 0,000 \\
\hline
\end{tabular}

Source: drawn from MCA7 program

In Table 20 the utility function is calculated.

Table 20: Calculation of the utility function

\begin{tabular}{|c|c|}
\hline Tenderer 1 & 1,000 \\
\hline Tenderer 2 & 0,000 \\
\hline
\end{tabular}

Source: drawn from MCA7 program

In Table 21 the tenders of tenderers are sorted from the best one to the worst.

Table 21: Tenders of tenderers sorted from the best to the worst

\begin{tabular}{|c|c|}
\hline Tenderer 1 & 1,000 \\
\hline Tenderer 2 & 0,000 \\
\hline
\end{tabular}

Source: drawn from MCA7 program

b) The TOPSIS method

In Table 22 a criterion matrix to maximization criteria is modified.

Table 22: Modification of a criterion matrix to maximization criteria

\begin{tabular}{|c|c|c|c|c|}
\hline Tenderer 1 & 450860,6 & 72 & 12983 & 15 \\
\hline Tenderer 2 & 0 & 36 & 2867 & 0 \\
\hline
\end{tabular}

Source: drawn from MCA7 program

In Table 23 the matrix is normalized for comparability of the data.

Table 23: The normalized matrix for comparability of the data

\begin{tabular}{|c|c|c|c|}
\hline 1,000 & 0,894 & 0,976 & 1,000 \\
\hline 0,000 & 0,447 & 0,216 & 0,000 \\
\hline
\end{tabular}

Source: drawn from MCA7 program

The vector weights of criteria is normalized vector weights $0,8 \quad 0,1 \quad 0,05 \quad 0,05$ the sum of the weights

In Table 24 the weighted criterion matrix is calculated.

Table 24: Calculated weighted criterion matrix

\begin{tabular}{|c|c|c|c|}
\hline 0,800 & 0,089 & 0,049 & 0,050 \\
\hline 0,000 & 0,045 & 0,011 & 0,000 \\
\hline
\end{tabular}

Source: drawn from MCA7 program 
In Table 25 an ideal and a basal variants are determined.

Table 25: Determination of an ideal and a basal variant

\begin{tabular}{|c|c|c|c|}
\hline 0,800 & 0,089 & 0,049 & 0,050 \\
\hline 0,000 & 0,045 & 0,011 & 0,000 \\
\hline
\end{tabular}

Source: drawn from MCA7 program

In Table 26 the distance from an ideal and a basal variants are calculated.

Table 26: Calculation of the distance from an ideal and a basal variant

\begin{tabular}{|c|c|c|c|}
\hline & di+ & di- & Ci \\
\hline Tenderer 1 & 0,000 & 0,804 & 1,000 \\
\hline Tenderer 2 & 0,804 & 0,000 & 0,000 \\
\hline
\end{tabular}

Source: drawn from MCA7 program

In Table 27 the tenders of tenderers are sorted from the best one to the worst.

Table 27: Tenders of tenderers sorted from the best to the worst

\begin{tabular}{|c|c|}
\hline Tenderer 1 & 1,000 \\
\hline Tenderer 2 & 0,000 \\
\hline
\end{tabular}

Source: drawn from MCA7 program

I came to a conclusion that the winner of the public contract (based on both methods) will be the real winner of this public contract, ie. ETL-Ekotherm a.s., Praha 2, Sekaninova 192/48, PSČ 12800 (see Table 21 and Table 27).

\section{Discussion of research findings}

Multi-criteria decision analysis while selecting suppliers in the public contract deal with many foreign authors in their articles, for examples: in Greece (Anagnostopoulos and Vavatsikos 2006), in Ghana (Enyinda et al. 2011), in Lithuania (Banaitiené and Banaitis 2006), in Spain (Pastor-Ferrando et al. 2010 and San Cristóbal 2012), in Taiwan (Hsieh et al. 2004 and Wang et al. 2013), in India (Puri and Tiwari 2014), in Hong Kong (Fong and Choi 2000) or in Portugal (Mateus et al. 2010).

Anagnostopoulos and Vavatsikos (2006) propose a multicriteria decision making approach, based on the Analytic Hierarchy Process (AHP), for supporting public authorities in contractor prequalification. The decision problem is decomposed into qualitative criteria and sub-criteria that are further analyzed in quantitative indicators on which the candidate contractors are evaluated. The advisory decision support system is an appropriate tool for at least three reasons: First, various criteria are included, in order to ensure the quality of the completed product. Second, it is easy to use, because, on the one hand, it requires no prior knowledge of multicriteria methods from the potential users; and, on the other hand, it minimizes subjective judgments. Finally, the model minimizes the required pairwise comparisons, which is considered to be a major default of AHP.

Enyinda et al. (2011) used the AHP model, because it allows different types of contractor capabilities to be examined. The result findings indicate that contractors' experience is the most important followed by manpower resources, financial stability, and relevant equipment for contractors' selection in Ghana.

According to Banaitiené and Banaitis (2006) the lowest price often cannot guarantee commitments on quality and duration of a construction project. Therefore, when selecting a contractor, a client must not only compare bid prices but also set other criteria for evaluation 
of qualification and determine their weight. A contractor must be selected according to both quantitative and qualitative criteria, and bids should be compared. Only on the basis of quantitative and qualitative evaluation criteria and by comparing bids of contractors it is possible to select a qualified, competent and reliable contractor, to evaluate its qualification, economic and financial condition and technical capability and skills and to achieve relevant results in a construction project. There are three prime causes of inadequate contractor selection. Firstly, inappropriate criteria are selected when evaluating qualification of a contractor. Secondly, inappropriate significance is attributed to the criteria (e g to bid price). Thirdly, inappropriate methodology is applied for the contractor evaluation and selection task. Pastor-Ferrando et al. (2010) in paper a new approach for the selection and measurement of the bidding criteria based on Analytic Hierarchy Processes (AHP) and Analytic Network Processes (ANP) is proposed. A hierarchy model and a 21-criterion network model have been developed and applied to two real cases: the first one is devoted to study the public bidding for the construction of an educational centre at the Polytechnic University of Valencia, whereas the second one analyses the public bidding for the remodelling and improvement of one section of a national road.

According to Hsieh et al. (2004) Fuzzy Analytic Hierarchy Process (FAHP) or Fuzzy Multiple Criteria Decision Making (FMCDM) analysis has been widely used to deal with decision-making (DM) problems involving multiple criteria evaluation/selection of alternatives.

Wang et al. (2013) in the work presented an adaptive AHP approach (A3) to improve the traditional AHP method of solving Multiple Criteria Decision Making (MCDM) problems from three perspectives: (1) cost effectiveness - the proposed A3 eliminates the reassessment process required by the traditional AHP approach, saving numerous man hours (and thus associated costs); (2) timeliness - the proposed A3 shortens the time required to gather the pairwise weighting matrix (PWM) reassessment data, allowing emergent MCDM problems to be solved in time; (3) improved decision quality - the proposed A3 enhances the decision quality, which better reflects the original belief of the decision makers in the relative importance relationships of the criteria.

Puri and Tiwari (2014) study aims at identifying the criteria for selection of contractor and bid evaluation means by which different emphases can be recommended to suit the requirements of clients and projects. The research was conducted by sending a questionnaire to different project managers in India and had an exceptionally high rate of response of $72 \%$. The result is a list of identified criteria and sub-criteria.

According to Fong and Choi (2000) some contractor selection methods currently in existence are criticized as incomplete and biased, and lacking consideration in terms of the contractor's ability to achieve simultaneously, time, cost, quality and safety standards. The research examines an alternative contractor selection model called the analytical hierarchy process (AHP), which will help construction clients to identify contractors with the best potential to deliver satisfactory outcomes in a final contractor selection process which is not based simply on the lowest bid. The AHP comprises three parts: hierarchic structure, prioritization procedure, and calculation of results. This model is tested by a hypothetical scenario where three contractor candidates are evaluated. The criteria used for contractor selection in the model have been identified, and the significance of each criterion has been arrived at by conducting a questionnaire survey in public organizations in Hong Kong. 
Mateus et al. 2010 in article outlines the feasibility of establishing such a comprehensive tender evaluation model in advance, addresses detailed instructions on how to go about in developing and applying it, and submits that existing European provisions on public procurement could yet go further in ensuring effective transparency, competition and best value for money tenders.

The evaluation committee in the Czech Republic most often uses the scoring method. In this article on the selection of a specific public contracts, where the basic criterion for awarding the contract is the economic advantageousness of the tender, the methods of multi-criteria decision analysis were applied, namely the methods WSA and TOPSIS and in order to ascertain whether the winner of the public tender is always the same tenderer. The winning tenderer was also true winner of the selection of the specific public contracts. The article reviews the appropriateness of the use of partial evaluation criteria and not just price as the only evaluation criterion in public procurement, criterion "the lowest tender price" should be used rarely, and while in the Czech Republic is in the most cases used "the lowest tender price" as the only evaluation criterion (see Table 1 and Figure 1). Article contributes to problem solving of the appropriateness of the use of partial evaluation criteria (economic advantageousness of the tender) in the evaluation of tenders in public procurement in the Czech Republic using multi-criteria decision analysis, ie. methods WSA and TOPSIS. According to San Cristóbal (2012) recently, to assist owners in making decisions, there has been a trend away from a "lowest-price wins" principle and subjective judgement to a multicriteria selection approach in the selection of contractors for construction projects. In the autonomous region of Cantabria, in the north of Spain, increased project complexity and higher requirements have recently demanded the use of multicriteria decision-making methods for contractor selection, namely the method TOPSIS.

Application of these methods (ie. methods WSA and TOPSIS) in the Czech Republic would be for contracting authorities better, preferable, more innovative. With a clear determination of the criteria in the procurement procedure using methods WSA and TOPSIS could be more appropriate for contracting authorities (for example Czech Republic, a state allowance organisation, a territorial self-governing unit or an allowance organisation, another legal person) than scoring method. Contracting authorities will prefer partial evaluation criteria (the economic advantageousness of the tender) before the criterion "the lowest tender price".

The method TOPSIS and her appropriateness uses also Behzadian et al. (2012), method developed to solve real-world decision problems, these methods can to work satisfactorily across different application areas. Also Zavadskas et al. (2012) use method TOPSIS. According to Zavadskas et al. (2012) decision on the most suitable construction technology is vital for success and depends on many effectiveness criteria. The business success depends on the right choice. Jafari (2013) also selection of the most appropriate contractor for the project is a critical decision for clients. The pre-qualification of construction contractors is accounted as a very important step in contractor selection for every project. The main purpose of prequalification is to identify an array of eligible contractors, which is required for postqualification steps and further considerations.

\section{Conclusion}

A significant number of contracting authorities in the Czech Republic state the price as the sole criterion for evaluating in the tender documentation, so the public contract is evaluated according to the lowest tender price. Using partial evaluation criteria requires more knowledge and experience of the contracting authorities. A clear formulation of partial 
evaluation criteria takes more time, both in preparation of the procedure, as well as during the award procedure. If the contracting authority wants to use partial (non-price) criteria for evaluating tenders, it must have good knowledge of the law. In practice it may also happen that if the only criterion in the selection of public contracts is the lowest tender price, an unreliable supplier will be chosen and everything will go at the expense of quality. A tenderer who submitted a tender with a low tender price, may be asked to substantiate this abnormally low tender price.

It should be emphasized that the use of non-price, ie. partial evaluation criteria can contribute to implementation of the fundamental principles of public procurement and to ensure a nondiscriminatory access to public procurement. Increasing the number of procedures for the award of public contracts, in which the selection of the advantageous tender will be made on the basis of non-price ie. partial evaluation criteria, could lead to increased competitiveness and allow tenderers to submit tenders with innovative solutions resulting in applying the principles of public finance related to the effective and rational spending of public funds.

For example, in the Republic of Poland it is stated that the lowest tender price as the sole criterion in the evaluation and assessment of tender is possible, but only if the subject of the contract is widely available and has established quality standards. The introduction of this type of provision in the law on public procurement in the Czech Republic would bring many benefits not only for contracting authorities, who are concerned about the best performance of public contracts, but also for the tenderers, as well as economic operators and companies. Partial evaluation criteria would be applied for more complex public contracts and highquality economic operators (companies), who would meet the criteria specified in the award procedure, not just price criterion, would be involved in the award procedure. There would be a greater chance that a public contract would be finalized in the highest quality. High quality economic operators would only benefit due to this provision. It would be appropriate to use the methods of the multi-criteria decision analysis, namely methods WSA and TOPSIS, for evaluating based on partial evaluation criteria. Application of these methods would be surely benefit for contracting authorities, but also for the tenderers.

For simple public procurements, where the subject of the procurement is widely available and has established its quality standards, the price could be set as a sole evaluation criterion. This group would involve available public contracts, which the market is saturated with, and the lowest tender price might be used to assess and evaluate the public contracts.

\section{Acknowledgement}

"This paper was supported by the project SGS/13/2015 "Influence of Selected Macroeconomic and Microeconomic Determinants on the Competitiveness of Regions and Firms in Countries of the Visegrad Group Plus".

\section{References}

[1] Act No.134/2016 Coll, on Public Procurement.

[2] Act No. 137/2006 Coll., on Public Contracts, as amended.

[3] ANAGnOStOpOUlos, K. P. and A. P. VAVATSiKOS, 2006. An AHP Model for Construction Contractor Prequalification. Operational Research. An International Journal, 6(3), 333-346. ISSN 1109-2858. 
[4] BANAITIENÉ, N. and A. BANAITIS, 2006. Analysis of criteria for contractors' qualification evaluation. Ukio Technologinis ir Ekonominis Vystymas, 12(4), 276-282. ISSN 1392-8619.

[5] BEHZADIAN, M. et al., 2012. A state-of the-art survey of TOPSIS applications. Expert Systems with Applications, 39(17), 13051-13069. ISSN 0957-4174.

[6] BRANNMAN, L. et al., 1987. The Price Effects of Increased Competition in Auction Markets. The Review of Economics and Statistics, 69(1), 24-32. ISSN 0034-6535.

[7] CARR, P. G., 2005. Investigation of Bid Price Competition Measured through Prebid Project Estimates, Actual Bid Prices, and Number of Bidders. Journal of Construction Engineering and Management, 131(11), 1165-1172. ISSN 0733-9364.

[8] DINÇER, S. E., 2011. Multi-criteria Analysis of Economic Activity for European Union Member States and Candidate Countries: TOPSIS and WSA Applications. European Journal of Social Sciences, 21(4), 563-572. ISSN 1450-2267.

[9] DVORSKÝ, J. et al., 2006. Software MCA8 for Computation of MCA Methods. Pp. 6677 in sbornik konference ELNET 2006. Ed. Václav Snášel. Ostrava: TiskServis Jiří Pustina.

[10] ENYINDA, C. I. et al., 2011. A Decision Support Model for Contractor Selection in a Government Procurement Supply Chain: Evidence from an Emerging Market. Journal of Management Policy and Practice, 12(7), 9-17. ISSN 1913-8067.

[11] Europe Economics, 2015. Procurement [online]. [cit. 2016-06-07]. Available from: http://www.europe-economics.com/page/56/procurement.htm

[12] FONG, P. S. W. and S. K. Y. CHOI, 2000. Final contractor selection using the analytical hierarchy process. Construction Management \& Economics, 18(5), 547-557. ISSN 1466$433 X$.

[13] GINEITIENÉ, Z. and K. ŠERPYTIS, 2011. The Impact of Competition and Purchase Volume on the Price in Public Procurement Tenders (article in Lithuanian). Societal studies, 3(2), 473-485. ISSN 2029-2236.

[14] GRANECKI, P., 2014. Prawo zamowień publicznych. Komentarz. 4. Wydanie. Warszawa: C.H.Beck. ISBN 978-83-255-6355-4.

[15] Hospodářská komora České republiky, 2015. Výroční zpráva o stavu veřejných zakázekv České republice za rok 2015 [online]. [cit. 2016-06-04]. Available from: http://www.komora.cz/pro-podnikani/legislativa-a-normy/pripominkovanilegislativy/nove-materialy-k-pripominkam/107-16-vyrocni-zprava-o-stavu-verejnychzakazek-v-ceske-republice-za-rok-2015-t-16-5-2016.aspx

[16] HSIEH, T. Y. et al., 2004. Fuzzy MCDM approach for planning and design tenders selection in public office buildings. International Journal of Project Management, 22(7), 573-584. ISSN 0263-7863.

[17] JABLONSKY, J. and P. FIALA, 2003. Models for Productivity Measurement of Central European Countries. Pp. 253-254 in ISAHP 2003 proceeding. Bali, Indonesia, August 79.

[18] JAFARI, A., 2013. A contractor pre-qualification model based on the quality function deployment method. Construction Management and Economics, 31(7), 746-760. ISSN 0144-6193. 
[19] JURČÍK, R., 2014. Veřejné zakázky a koncese. 2. dopl. vydání. Praha: C.H. Beck. ISBN 978-80-7400-443-8.

[20] JURČÍK, R., 2015. New Trends in the Evaluation of Public Contracts. The Lowest Tender Price or Economic Advantageousness of the Tender? In D. SPALKOVA a L., FUROVA, eds. Proceedings of the 19th International Conference on Modern and Current Trends in the Public Sector Research. Brno: Masaryk University. pp. 125-133. ISBN 978-80-210-7532-0. ISSN 2336-1239.

[21] KASHAP, S., 2004. Public Procurement as a Social, Economic and Political Policy. In: Challenges in Public Procurement: An International Perspective (vol. 3), International Public Procurement Conference. Florida, USA, pp. 133 - 147 Available from: http://www.ippa.ws/IPPC1/PROCEEDING\%20PAPERS/Kashap.pdf

[22] KRČ, R., 2013. Zákon o veřejných zakázkách s komentářem a judikaturou. Praha: Linde a.s. ISBN 978-80-7201-888-8.

[23] MATEUS, R. et al., 2010. Full Disclosure of Tender Evaluation Models: Background and Application in Portuguese public procurement. Journal of Purchasing \& Supply Management, 16(3), 206-215. ISSN 1478-4092.

[24] Ministry of Regional Development, 2014. Výroční zpráva o stavu veřejných zakázek v České republice za rok 2014 [online]. [cit. 2015-08-22]. Available from: http://www.portal-vz.cz/getmedia/e404b766-77d0-488b-8809-6951c53c0eb9/Vyrocnizprava-o-stavu-verejnych-zakazek-v-Ceske-republice-za-rok-2014_final.pdf

[25] OECD Principles for Integrity in Public Procurement, 2009. [online]. [cit. 2015-06-07]. Available from: http://www.oecd.org/gov/ethics/48994520.pdf

[26] OCHRANA, F. and J. PAVEL, 2013. Analysis of the Impact of Transparency, Corruption, Openness in Competition and Tender Procedures on Public Procurement in the Czech Republic. Central European Journal of Public Policy, 7(2), 114 - 135. ISSN 1802-4866.

[27] ONUR, İ. et al., 2012. Public Procurement Auctions and Competition in Turkey. Review of Industrial Organization, 40(3), 207-223. ISSN 0889-938X.

[28] PASTOR-FERRANDO, J.P. et al., 2010. An ANP-and AHP-based approach for weighting criteria in public works bidding. The Journal of the Operational Research Society, 61(6), 905-916. ISSN 0160-5682.

[29] PAVEL, J., 2010. Analýza vlivu míry konkurence na cenu rozsáhlých staveb dopravní infrastruktury. Politická ekonomie, 58(3), 343-356. ISSN 0032-3233.

[30] PURI, D. and S. TIWARI, 2014. Evaluating The Criteria for Contractors' Selection and Bid Evaluation. International Journal of Engineering Science Invention, 3(7), 44-48. ISSN $2319-6734$.

[31] RADZISZEWSKA - ZIELINA, E., 2011. Public Procurement Procedure in Construction in Poland And Problems With its Application. Organization, Technology \& Management in Construction: An International Journal, 3(1), 269-275. ISSN 1847-5450.

[32] THAI, K. V., 2009. International Handbook of Public Procurement. Florida: CRC Press. ISBN 978-1-4200-5457-6.

[33] SAN CRISTÓBAL, J. R., 2012. Contractor Selection Using Multicriteria DecisionMaking Methods. Journal of Construction Engineering and Management, 138(6), 751758. ISSN 0733-9364. 
[34] SKÁLOVÁ, M., 2014. Konec nejnižší nabídkové ceny jako základního hodnotícího kritéria pro zadání veřejné zakázky? epravo.cz [online]. 30. května 2014 [vid. 23. listopadu 2015]. Dostupné z: http://www.epravo.cz/top/clanky/konec-nejnizsi-nabidkoveceny-jako-zakladniho-hodnoticiho-kriteria-pro-zadani-verejne-zakazky-94324.html

[35] ŚMIGULSKA-WOJCIECHOWSKA, A., 2014. Cena jako jedyne kryterium oceny ofert tylko w określonych sytuacjach. PortalZP.pl [online]. [cit. 2015-08-25]. Available from: https://www.portalzp.pl/aktualnosci/cena-jako-jedyne-kryterium-oceny-ofert-tylko-wokreslonych-sytuacjach-1350442

[36] WANG, W. CH. et al., 2013. Applying the AHP to support the best-value contractor selection - lessons learned from two case studies in Taiwan. Journal of Civil Engineering and Management, 19(1), 24-36. ISSN 1392-3730.

[37] ZAVADSKAS, E. K. et al., 2012. Multiple criteria selection of pile-column construction technology. Journal of Civil Engineering and Management, 18(6), 834-842. ISSN 13923730 .

[38] Zpráva o posouzení a hodnocení nabídek [online]. [cit. 2016-02-07]. Available from: file:///C:/Users/uzivatel/Downloads/zpr\%C3\%A1 va\%20o\%20posouzen\%C3\%AD\%20a \%20hodnocen\%C3\%AD\%20nab\%C3\%ADdek\%20(2).pdf

[39] Zpráva o posouzení a hodnocení nabídek [online]. [cit. 2016-02-07]. Available from: http://www.poliklinikaprosek.cz/soubor-zprava-o-posouzeni-a-hodnoceni-nabidek-39-pdf 